\title{
Clinically Evident, Non-terminal Infections with Herpesviruses and the Wart Virus in Immunosuppressed Renal Allograft Recipients
}

\author{
EDWIN S. SPENCER,* M.D. ; HANS K. ANDERSEN, † V.M.D.
}

\begin{abstract}
Uummary: The clinical incidence of herpes simplex lesions, herpes zoster, cytomegalovirus infection, and warts has been determined in a group of renal allograft recipients. Herpes simplex lesions appeared to be no more common after transplantation than before in those patients subject to recurrent attacks. Among 74 patients there were seven cases of herpes zoster and seven serologically proved cases of cytomegalovirus infection with clinical manifestations. The incidence of warts increased with length of time after transplantation, $42 \%$ of patients being affected more than one year after transplantation. All of the viral infections studied behaved as in healthy adults, and serious illness, dissemination, widespread lesions, and complications were not seen. No factors other than immunosuppression and steroid therapy could be identified with certainty as predisposing to these infections.
\end{abstract}

\section{Introduction}

Viral infections, particularly with members of the herpes group of viruses, are not uncommon in patients given immunosuppressive agents and prolonged steroid therapy. Thus renal allograft recipients are especially prone to develop these infections. The present report concerns the clinical incidence of herpes simplex, herpes zoster, cytomegalovirus infection, and warts among 74 patients who had been given a kidney transplant. Where possible the antibody response was also studied.

\section{Patients and Methods}

Eighty-three patients received renal grafts at this centre up to 1 July 1969. Only those treated with azathioprine, an immunosuppressive agent, and prednisone for at least one month are included in the present survey. Nine of the 83 patients did not meet this requirement because of early graft failure, death, or receipt of an isograft. The final study group thus consisted of 74 patients ( 35 female and 39 male) aged 12 to 52 (mean 31) years, of whom 55 were alive at the time of the study.

Immunosuppression.-Azathioprine, 2 to $4 \mathrm{mg}$. $/ \mathrm{kg}$., was given from the time of or from a few days before transplantation. The dosage of the agent was adjusted so that the white blood cell count remained between 5,000 and $10,000 \mathrm{c} . / \mathrm{mm}$. Prednisone 300 to $150 \mathrm{mg}$./day was started at the first sign of rejection-an event almost always occurring during the first post-transplant week-and thereafter reduced stepwise to a maintenance dose of 10 to $20 \mathrm{mg}$./day, unless renewed evidence of rejection appeared, whereupon the dose was again increased. Actinomycin C, $200 \mu \mathrm{g}$. every other day for four to six days, was used at the time of a rejection crisis in some patients. If a rejection crisis could not be reversed by prednisone, $150 \mathrm{r} x$-irradiation was given to the graft on alternate days for a total exposure of $600 \mathrm{r}$.

\footnotetext{
* Medical Registrar, Medical Department C, Aarhus Kommune Hospital,

Aarhus, Denmark.
t Lecturer, Institute of Medical Microbiology, Aarhus University, Aarhus, Denmark.
}

Where adequate serum samples were available complement-fixing antibody titres were determined against herpes simplex virus in patients with either prolonged or extensive herpetic lesions and against varicella-zoster virus in patients with herpes zoster (shingles). In patients with fever of undetermined or unclear origin cytomegalovirus complementfixing antibody was measured and the Paul-Bunnell test for heterophil agglutinin performed. Complement fixation tests used in these investigations are those described by Andersen and Spencer (1969). Herpes simplex virus antigen was produced in HeLa cultures with herpes simplex virus strain from the Statens Seruminstitut, Copenhagen, and cytomegalovirus antigen was produced in human embryonic lung cultures with strain Ad 169. Varicella-zoster antigen was prepared from the cellular phase of WI-38 cultures after infection with zoster virus (strain EY) isolated by Rapp and BenyeshMelnick (1963). All sera from each patient were titrated simultaneously. Seroconversion or a fourfold titre rise was regarded as evidence of infection.

The Paul-Bunnell test was performed after adsorption with guinea-pig kidney tissue and bovine erythrocytes as described by Buescher (1964). The maximum titre read in sera taken in connexion with febrile episodes was 40 in three patients and 80 in one.

All hospital records were carefully perused and all living graft recipients personally interviewed. Only living patients were included in the study of herpes simplex infections and warts as hospital records were felt to be inadequate for investigation of these conditions.

\section{Results}

\section{Herpes Simplex}

Of the 55 living patients in the study 16 had suffered from "cold sores"- that is, herpes simplex lesions about the mouth-before transplantation. Only one of these, however, noted an increased occurrence after transplantation. Indeed six patients felt that they had fewer outbreaks. Two developed confluent labial herpetic sores eight and 210 days after transplantation. In both patients lesions subsided in the course of about two weeks. A herpes simplex virus complementfixing antibody rise could be demonstrated in one of these two patients. Two additional patients had small labial lesions at the time of transplantation. These lesions persisted for an excessive period of time, finally disappearing two to three months after transplantation. Again the antibody rise was seen in one, but not in the other. All four patients had complement-fixing antibody against herpes simplex virus in pretransplant sera. Herpes simplex lesions at sites other than around the mouth and disseminated and widespread lesions have not been seen. Neither have herpetic lesions been observed in patients not having had such lesions before transplantation or not evidencing herpes simplex virus complement-fixing antibodies in pre-transplant serum samples. Thus it seems permissible to say that there have been no primary cases of herpes simplex virus infection in our patients. 


\section{Herpes Zoster}

Seven of the 74 patients had a typical zoster rash. Six could remember having suffered from chicken-pox (varicella) as children. One patient (Case 60) was quite sure that she had never had chicken-pox. None of these seven patients had previously been afflicted with shingles and most of those who did not develop shingles had experienced chicken-pox. Varicella has not been seen after transplantation in our patients.

The zoster lesions developed 84 to 686 days after transplantation, at a time when all but one patient (Case 64) were on maintenance steroid and immunosuppressive therapy (Table I). The temporal relationship between exposure to $x$ irradiation and the onset of the zoster rash is noted in Table I. In only one patient did there seem to be a clear-cut relationship. This patient had been given $600 \mathrm{r}$ two weeks before the rash appeared. No other known predisposing factors could be identified. Five of the seven patients were being treated with diuretic agents, a higher incidence than in the series as a whole, but in no other way did the management of these patients appear to differ from that of patients not developing shingles. In particular there was no difference between the magnitude and kind of immunosuppressive therapy used.

The zoster lesion involved from two to five dermatomes and subsided in all patients in the course of three to four weeks. Dissemination, facial involvement, and residual neuritis were not seen. Sera adequate for serological investigation were available from five of the seven patients and a signifi- cant rise in varicella-zoster virus complement-fixing antibody titre was found in all.

\section{Cytomegalovirus Infection}

There were seven clinical episodes of what on serological data appear to have been cases of cytomegalovirus infection among the 74 patients studied. Clinical data concerning these patients are given in Table II. The clinical histories of three patients (Cases 29, 37, and 40) have been given elsewhere (Andersen and Spencer, 1969). Case 10 was briefly mentioned in the same publication.

Five of the seven presented a clinical syndrome with prolonged fever, leucopenia, lymphocytosis, and the appearance of virocytes in the peripheral blood. Two patients had fever only. In addition to fever two had diarrhoea, one rhinitis, and two a dry cough. Malaise was a complaint in two, but the others experienced almost no feeling of illness. Definite lung involvement was not seen, and in no case did significant illness result.

Symptoms appeared from 15 to 132 days after transplantation. Two patients (Cases 51 and 61) were being treated for a rejection crisis at the time and were therefore receiving large doses of prednisone. The others were on low to moderate doses. No factors could be determined that definitely differentiated these patients from those who did not develop a cytomegalovirus infection.

Seroconversion in cytomegalovirus complement-fixing antibody was seen in close association with the above-men-

TABLE I.-Clinical Features of Herpes Zoster in Seven Renal Allograft Recipients

\begin{tabular}{|c|c|c|c|c|c|c|c|c|c|}
\hline $\begin{array}{l}\text { Case } \\
\text { No. }\end{array}$ & $\begin{array}{l}\text { Age } \\
\text { and } \\
\text { Sex } \\
\end{array}$ & Dermatome & $\begin{array}{c}\text { Onset } \\
\text { (Day Post-transplant) }\end{array}$ & $\begin{array}{c}\text { Significant Rise } \\
\text { V-ZV. C.F. Titre } \\
\text { (Days Post-transplant) }\end{array}$ & $\underset{\text { Creatinine }}{\text { Serum }}$ & $\begin{array}{l}\text { Azathioprine } \\
\text { (mg./day) }\end{array}$ & $\begin{array}{l}\text { Prednisone } \\
\text { (mg./day) }\end{array}$ & $\begin{array}{l}\text { Other Drugs } \\
\text { Given }\end{array}$ & $\begin{array}{c}\text { Last Given } \\
\boldsymbol{x} \text {-irradiation } \\
\text { (Day Post-transplant) }\end{array}$ \\
\hline 2 & $36 \mathrm{~F}$. & Left $T-9,10,11$ & 173 & Inadequate sera & $1 \cdot 3$ & 125 & $2 \frac{1}{2}$ & $\begin{array}{l}\text { Guanethidine } \\
\text { Hydrochlorothiazide }\end{array}$ & 133. I.V. urography \\
\hline 16 & $44 \mathrm{M}$. & Right T-9,10 & 644 & $630-715$ & $1 \cdot 0$ & 125 & 10 & None & 513. Chest film \\
\hline 22 & $24 \mathrm{M}$. & Left $T-4,5$ & 686 & $675-703$ & $1 \cdot 3$ & 125 & $17 \cdot 5$ & $\begin{array}{l}\text { Guanethidine } \\
\text { Cyclopenthiazide }\end{array}$ & 635. Chest film \\
\hline 24 & $31 \mathrm{M}$. & Left $T-4,5,6,7$ & 446 & $417-549$ & 1.9 & 125 & $17 \cdot 5$ & $\begin{array}{l}\text { Guanethidine } \\
\text { Cyclopenthiazide }\end{array}$ & 172. Chest film \\
\hline 28 & $26 \mathrm{M}$. & Left $T-4,5$ & 435 & $437-445$ & $1 \cdot 4$ & 75 & 15 & None & $\begin{array}{l}\text { 285. Chest film, bone } \\
\text { series }\end{array}$ \\
\hline 60 & $21 \mathrm{~F}$. & Right $T-1,2,3,4,5$ & 100 & $98-129$ & $1 \cdot 2$ & 100 & $17 \cdot 5$ & Cyclopenthiazide & 70. Chest film \\
\hline 64 & $41 \mathrm{~F}$. & Right $T-10,11,12$ & 84 & Inadequate sera & $3 \cdot 5$ & 50 & 75 & $\begin{array}{l}\text { Frusemide } \\
\text { Spironolactone }\end{array}$ & $\begin{array}{l}67-71.600 \mathrm{r} \text { to } \\
\text { left renal graft }\end{array}$ \\
\hline
\end{tabular}

V.-Z.V. = Varicella-zoster virus

TABLE II.-Clinical Features of Cytomegalovirus Infection in Seven Renal Allograft Recipients

\begin{tabular}{|c|c|c|c|c|c|c|c|c|c|c|c|}
\hline \multirow[t]{2}{*}{$\begin{array}{l}\text { Case } \\
\text { No. }\end{array}$} & \multirow{2}{*}{\multicolumn{2}{|c|}{$\begin{array}{l}\text { Age } \\
\text { and } \\
\text { Sex }\end{array}$}} & \multirow[t]{2}{*}{$\begin{array}{c}\text { Seroconversion in } \\
\text { CMV }{ }^{*} \text {, C.F. Titre Between } \\
\text { Post-transplant Days }\end{array}$} & \multirow{2}{*}{$\begin{array}{l}\text { Rise in Paul-Bunnell } \\
\text { Titre to } \leqslant 80 \\
\text { (Day Post-transplant) }\end{array}$} & \multicolumn{4}{|c|}{$\begin{array}{l}\text { Symptoms of CMV Infection } \\
\text { (Day Post-transplant) }\end{array}$} & \multirow{2}{*}{$\begin{array}{l}\text { Creatinine } \\
\text { Clearance } \\
\text { (ml./min.) }\end{array}$} & \multicolumn{2}{|c|}{$\begin{array}{l}\text { Immunosuppression } \\
\text { During Period of } \\
\text { Symptoms }\end{array}$} \\
\hline & & & & & $\begin{array}{c}\text { Fever } \\
>37.5^{\circ} \mathrm{C} \\
\end{array}$ & $\begin{array}{l}\text { Leucopenia } \\
<5,000 / \mu l \text {. }\end{array}$ & $\begin{array}{c}\text { Lymphocytosis } \\
>30 \%\end{array}$ & $\begin{array}{c}\text { Other } \\
\text { Symptoms }\end{array}$ & & $\begin{array}{c}\text { Azathioprine } \\
\text { (mg./day) }\end{array}$ & $\begin{array}{c}\text { Prednisone } \\
\text { (mg./day) }\end{array}$ \\
\hline 10 & & M. & $9-45$ & 95 & $15-43$ & None & None & $\begin{array}{l}\text { Substernal } \\
\text { pain }\end{array}$ & $55-65$ & $150-25$ & $30-20$ \\
\hline 29 & 18 & F. & $41-56$ & No rise & $43-71$ & None & None & $\begin{array}{l}\text { Dry cough, } \\
\text { headache, } \\
\text { nausea, } \\
\text { malaise }\end{array}$ & $50-80$ & $100-75$ & $55-15$ \\
\hline 37 & 51 & F. & $(-5)-31$ & No rise & $45-51$ & $47-53$ & $47-53$ & Dry cough & $40-60$ & $0-50$ & $35-30$ \\
\hline 40 & 21 & F. & $95-103$ & 99 & $83-97$ & $88-100$ & $100-124$ & $\begin{array}{c}\text { Rhinitis, } \\
\text { malaise }\end{array}$ & $70-80$ & $50-65$ & $30-20$ \\
\hline 51 & & F. & $40-47$ & No rise & $33-54$ & $38-41$ & $41-54$ & Diarrhoea & $30-55$ & $0-50$ & $150-65$ \\
\hline 61 & 12 & F. & $103-118$ & 103 & 105 & $102-118$ & 116 & Diarrhoea & $40-50$ & $25-50$ & $75-60$ \\
\hline 63 & & F. & $46-137$ & 137 & $132-140$ & $117-120$ & $117-120$ & None & $60-80$ & $25-50$ & $7\}$ \\
\hline
\end{tabular}


tioned episodes of clinical illness (Table II)-in one just before the onset of symptoms, in the others during the period of symptoms. In addition a slight non-significant rise in heterophil agglutinins was seen in four patients-in three simultaneously with cytomegalovirus complement-fixing seroconversions and in one immediately before seroconversion.

\section{Warts}

Fourteen of the 55 living graft recipients in this series have been afflicted with small common warts-on the foot in one, on the cheek in another, and on the fingers and hands in the rest. The chance of a patient developing warts increased with time. None of the 21 patients surviving one year or less had warts, whereas the incidence was $42 \%$ (14 out of 34 ) among allograft recipients more than one year after transplantation. Once warts appeared a patient was never free of them, new crops continuing to appear. All patients developing warts had had them as children or adolescents.

\section{Discussion}

Most of the viral infections observed in this study were probably caused by activation of an endogenous virus. All herpesviruses are known to produce latent infections, and the presence of herpes simplex virus complement-fixing antibodies in all pre-transplant sera from patients with herpes simplex lesions, and the finding that five out of seven patients thought to have cytomegalovirus infections had virusneutralizing antibodies in their serum before the onset of symptoms, suggest that the herpes simplex and cytomegalovirus infections did result from the reactivation of a latent infection. It is generally believed that most cases of herpes zoster result from the activation of a latent varicella-zoster infection. Six of the seven patients with shingles could remember having had chicken-pox as children, and a latent infection could have persisted after disappearance of symptoms in childhood. It is not known whether wart virus can assume a latent state after primary infection. All patients developing warts after transplantation had been afflicted by warts as children or young adults, and it is possible that here, too, we are dealing with reactivation of a latent infection.

In this present study we found a high incidence of varicella-zoster, cytomegalovirus, and wart virus infections. Other investigators have presented similar findings as regards cytomegalovirus infection (Rifkind et al., 1967; Craighead et al., 1967) and herpes zoster (Rifkind, 1966), though there are apparently no reports on the incidence of warts in patients after renal transplantation-or for that matter in patients in general. Though warts are not uncommon in adults the incidence found in the present series-that is, $42 \%$ in graft recipients more than one year after transplantation-seems to be above that expected in a group of nonimmunosuppressed patients of the same age (Spencer, 1969). Because of the reduced resistance to clinical infection found for two of the herpesviruses, varicella-zoster virus and cytomegalovirus, it would not be surprising if the same held true for herpes simplex virus. This was, however, not the case. In fact, some patients had fewer outbreaks of herpes labialis after transplantation than they had experienced before operation. This observation agrees with the findings of Rifkind (1964) but not of Montgomerie et al. (1969).

In the present study no relation could be found between clinical viral infection and graft function, general condition of the patient, actinomycin C administration, or amount of azathioprine and prednisone given. In only one patient (Case
64) did viral infection follow leucopenia resulting from azathioprine toxicity. There did appear to be a relationship between length of immunosuppression and type of infection. Cytomegalovirus infections tended to occur during the first few months after transplantation and warts more than one year after operation. Zoster infections were more spread out, appearing from three months to almost two years after transplantation. The only prolonged outbreaks of herpes labialis were seen in close association with transplantation itself.

Rifkind (1966) reporting on six patients with shingles after renal transplantation found that five of them had been exposed to $x$-irradiation 5 to 23 days before the onset of the rash. In our series two out of seven patients had received $x$-irradiation in the month before the zoster rash appeared. No other predisposing factors were evident. but an observation of unknown significance is that five of the seven patients with shingles were receiving a diuretic agent.

The course and clinical manifestations of the viral infections studied differed little from what is seen in healthy individuals with the same infections. Disseminated and widely extensive infections were not observed. Two patients had protracted herpetic lesions, but both were receiving large doses of steroids as treatment for threatening rejection. The delaved healing of the sores probably represented a direct steroid effect rather than an increased virulence of virus or a reduced host resistance.

The diagnosis of herpes labialis, shingles, and warts can be made on the basis of inspection alone, but cytomegalovirus infection demands positive serological evidence for confirmation. In our series seroconversion in cytomegalovirus complement-fixing antibody has been seen in seven patients in close association with symptoms that have previously been described as occurring with cytomegalovirus infections. The most common clinical picture consisted of a febrile episode accompanied by mild leucopenia and relative lymphocytosis with the appearance of atypical lymphocytes of the virocyte type in the peripheral blood. With the exception of leucopenia these symptoms are often seen in healthy individuals with cytomegalovirus infections (Carlström et al., 1968; Klemola et al., 1969) and have been noted in renal allograft recipients (Andersen and Spencer, 1969; Balakrishnan et al., 1969). In addition, cough, headache, nausea, malaise, rhinitis, and diarrhoea were observed. All have previously been reported in patients with cytomegalovirus infections (Carlström et al., 1968).

The chief complaint of one patient (Case 10) was burning substernal pain on swallowing. Perhaps this was a case of cytomegalovirus oesophagitis, a not unknown complication in renal allograft recipients (Khastagir et al., 1969). Four of the seven patients suspected of having cytomegalovirus infection (Cases 10, 40, 61 and 63) also had a rise in heterophil agglutinins at the time of cytomegalovirus complement-fixing antibody seroconversion. It is not unlikely that they had a mixed infection. The Epstein-Barr virus, which is thought to be the causative agent in infectious mononucleosis, is a member of the herpes group of viruses, and, in view of the reduced resistance to infection by other members of this group found in the present study, it is quite possible that infections with this virus are also common in renal allograft recipients.

The reason for the increased incidence of herpes zoster, cytomegalovirus infections, and warts is undoubtedly related to the depressive effect immunosuppressive agents have on humoral and cellular immunity (Swanson and Schwartz, 1967; Rowley et al., 1969). Steroid therapy has been shown to reduce interferon production in mice (Haahr, 1969) and this effect of steroids may also have played a part in predisposing the patients in our series to viral infections.

We wish to thank Dr. Annelise Godtfredsen, Statens Seruminstitut, Copenhagen, for carrying out the complement fixation tests with varicella-zoster antigen. 
REFERENCES

Andersen, H. K., and Spencer, E. S. (1969). Acta Medica Scandinavica, 186,7 .

Balakrishnan, S. L., Armstrong, D., Rubin, A. L., and Stenzel, K. H. (1969). Fournal of the American Medical Association, 207, 1712.

Buescher, E. L. (1964). In Diagnostic Procedures for Viral and Rickettsial Diseases, ed. E. H. Lennette and N. J. Schmidt, p. 735. New York, American Public Health Association.

Carlström, G., et al. (1968). British Medical Fournal, 2, 521.

Craighead, J. E., Hanshaw, J. B., and Carpenter, C. B. (1967). Fournal of the American Medical Association, 201, 725.

Haahr, S. (1969). Acta Pathologica et Microbiologica Scandinavica, 75, 303. Khastagir, B., Montandon, A., Nakamoto, S., and Kolff, W. J. (1969). Archives of Internal Medicine, 123, 8.
Klemola, E., et al. (1969). Annals of Internal Medicine, 71, 11.

Montgomerie, J. Z., Becroft, D. M. O., Croxson, M. C., Doak, P. B., and North, J. D. K. (1969). Lancet, 2, 867.

Rapp, F., and Benyesh-Melnick, M. (1963). Science, 141, 433.

Rifkind, D. (1964). In Experience in Renal Transplantation, ed. T. E. Starzl, p. 213. Philadelphia, Saunders.

Rifkind, D. (1966). Fournal of Laboratory and Clinical Medicine, 68, 463.

Rifkind, D., Goodman, N., and Hill, R. B. (1967). Annals of Internal Medicine, 66, 1116.

Rowley, M. J., Mackay, I. R., and McKenzie, I. F. C. (1969). Lancet, 2, 708.

Spencer, E. S. (1969). Lancet, 1, 777.

Swanson, M. A., and Schwartz, R. S. (1967). Nerw England fournal of Medicine, 277, 163.

\title{
Clinical Trial of Iron Therapy on Psychomotor Function in Anaemic Women
}

\author{
P. C. ELWOOD,* M.D. ; DAFYDD HUGHES, $†$ M.B., B.CH., D.P.M.
}

\begin{abstract}
Gummary: A variety of aspects of psychomotor function $D$ were assessed in 47 women before and after iron therapy. These women, all of whom had initial haemoglobin levels below $10.5 \mathrm{~g} . / 100 \mathrm{ml}$., had been drawn from a population sample of 2,283 women seen at a haematological screening survey. There was no evidence of any beneficial effect of a rise in haemoglobin level on psychomotor function or on symptoms. Possibly this is because if an effect does occur it is unlikely to be apparent unless the haemoglobin level is very low. If this is true then anaemia is probably a rare cause of symptoms or impairment in psychomotor function in the community.
\end{abstract}

\section{Introduction}

The importance of iron deficiency in realistic terms of increased morbidity and impairment of function has not been fully established. In earlier studies its effect on symptoms and on cardiorespiratory function was examined (Cotes et al., 1969; Elwood et al., 1969). In this paper the effect of iron therapy on the psychomotor function of a population sample of anaemic women is examined.

\section{Method}

All the women aged 20 years and over who lived in a defined area in a Welsh mining valley were visited and invited to attend a haematological screening survey. A sample of venous blood was taken for estimation of haemoglobin level (as g./100 ml.) and packed cell volume (as \%).

Women found to have haemoglobin levels below $10.5 \mathrm{~g}$. were visited at home and asked about symptoms which might suggest the presence of a serious underlying condition; blood films were prepared to exclude a macrocytic anaemia. Investigation at hospital was offered where appropriate. They were then asked to co-operate in a study of the effect of iron therapy on a variety of simple performance tests. Those who agreed were given these tests at home, and then randomly allocated, in a ratio of $4: 3$, to iron (150 mg. Fe as ferrous carbonate daily) or given tablets of similar appearance which contained no iron. At the end of eight weeks' treatment a further sample of blood was taken and each of the performance tests repeated. All the women who were still anaemic were then given oral iron until their haemoglobin level was above $12 \mathrm{~g}$.

* Member of Medical Research Council Epidemiology Unit, Cardiff. †On Scientific Staff, Medical Research Council, Cardiff.
The performance tests were chosen to cover a range of psychomotor functions, from an almost pure test of intellectual function to a simple test of manual dexterity. They were administered by two trained observers who were blind to the treatment given. The conditions under which the tests were done and the instructions given to each subject were standardized as carefully as possible, and the results of the first series were unknown to the observers when the tests were repeated at the end of treatment.

(1) Serial Sevens.-The subject is instructed to subtract seven repeatedly from 100 , stating the answer at each subtraction. The time taken for 14 subtractions, regardless of errors and the number of errors, is recorded. A different starting number was used on the second test to minimize the learning effect. This is a pure test of intellectual function involving concentration, arithmetic reasoning, and short-term memory.

(2) E Test.-A page of printed text is presented to the subject and she is told to cross out every letter " $e$ " as quickly as possible. After one and two minutes the subject is encouraged to go more quickly. The number of E's crossed out in three minutes is recorded. This test involves vigilance, concentration, and a degree of dexterity.

(3) Maze Test.-This test is a boldly printed spiral maze (Gibson, 1964). The subject is asked to draw a line which does not touch the edge or any of a number of obstacles in the path of the maze. At 15-second intervals the subject is told to go more quickly. The time taken to complete the test is recorded and the errors where the line left the maze are scored. Comparisons are made in terms of this score as a regression on the time taken. This test requires attention, concentration, and agility in motor function.

(4) Card Sorter.-This is a modified form of a test used in a Himalayan expedition in 1960-1 to detect the effect of anoxia on performance (Pugh, 1962). Playing-cards are sorted by suit into appropriate sections in a box for six minutes after a practice run for one minute. If after a card has entered the box there is a delay of more than a preset interval of 1.5 seconds, this is detected electronically and a loud clicking noise is emitted until the next card enters. The number of such delayed responses, and their total duration in excess of 1.5 seconds, are recorded and are here referred to as "number" and "time" respectively. After one, three, and five minutes of the test the subject is encouraged to go more quickly. This test involves sustained repetitive decision making, co-ordination, and manual dexterity. As it is a protracted test, and was the last test administered, it is likely that subjects susceptible to fatigue will perform badly.

(5) Peg Board.-Forty-eight small wooden pegs, each in a hole in a board, are taken out one at a time, turned upside down, and replaced. The time in seconds to complete this is measured. This is a simple test of manual dexterity. 